\title{
Az UNIÓS FORRÁSOK FELHASZNÁLÁSÁNAK TANULSÁGAI A KÖZOKTATÁSBAN A NEMZETKÖZI ÉS HAZAI SZAKIRODALOM TÜKRÉBEN
}

\author{
LANNERT JUDIT
}

T-TUDOK Zrt.

A tanulmány az uniós források felhasználásának eredményességét vizsgálja a magyar közoktatás terén, és annak okát kutatja, hogy mi állhat a kudarcok mögött. A külföldi és hazai fejlesztéspolitikai szakirodalom alapján sorra veszi a lehetséges okokat, valamint a tipikus hibákat. A tanulmány végeredményben arra a következtetésre jut, hogy nem pusztán a nem megfelelő célkitűzésekkel, eszközök kiválasztásával, az implementáció nehézségeivel és az értékelés elmaradásával magyarázhatjuk az eredmények elmaradását. Eleve a kiindulás tűnik elhibázottnak, hiszen a közoktatás, ami egy diszkrecionális döntésekkel teli, tranzakcióintenziv terület, eredendően nem illik bele a nagy volumenü, rutinizált adminisztratív úton ellenőrzött projektek logikájába. Az Európai Unió fejlesztéspolitikáját újra kellene gombolni.

Kulcsszavak: oktatásfejlesztés, uniós források, implementáció, fejlesztéspolitika, visszacsatolás, eredményesség, szakmapolitika, strukturális alapok, jó gyakorlat, ügynök-megbízó probléma

The study examines the effectiveness of the use of EU funds in the field of public education in Hungary and investigates the reasons behind the failure. Based on the foreign and domestic development policy literature, it lists the possible causes as well as the typical mistakes. In conclusion, the study concludes that not just inadequate objectives or tools, the problems of implementation and the lack of evaluation can explain the lack of results. Initially, the starting point seems to be false, as public education, which is a transaction-intensive field with discretionary decisions, does not fit in with the logic of largescale, routine-controlled projects. The European Union's development policy should be reshuffled.

Keywords: development of education, EU funds, implementation, development policy, feedback, effectiveness, educational policy, structural funds, best practice, principal-agent problem 


\section{Bevezetés $^{1}$}

$\mathrm{N}$ apjainkban tudásalapú társadalomról beszélünk, de mind a jövedelmeket, mind a tudásjavakat illetően egyre nagyobb egyenlőtlenséggel találkozunk. Ezek feloldására a fejlett világ már több évtizede próbál fejlesztéspolitikai megoldásokat kitalálni, mégis a tátongó különbségeket a mai napig nem sikerült csökkenteni. Az Európai Unión belül is a strukturális alapokon keresztül próbálják a tagállamok közötti egyenlőtlenségeket felszámolni, egyelőre kétes sikerrel. A magyar közoktatás fejlesztésére is sok európai uniós forrást használtunk fel. Mégis a PISA-adatokból úgy tűnik, hogy az oktatás minőségén nem sikerült jelentősen javítani az elmúlt másfél évtizedben. Vajon hol rontottuk el? Nem jól tüztük ki a célokat? Nem jó diagnózist állítottunk fel? Talán az eszközökkel volt a gond, vagy az implementálással? Vagy lehet, hogy már a fejlesztéspolitikai elképzelések alapkoncepciója is hibásnak bizonyult? A tanulmány arra keresi a választ, hogy vajon milyen tanulságot vonhatunk le a világbanki és európai uniós fejlesztési tapasztalatok alapján az oktatásügy terén.

\section{Sikeresnek mondhatók-e az eddigi fejlesztések?}

$\mathrm{A} z$ uniós pénzek lehívási aránya talán az egyik legerőteljesebb kormányzati sikerindikátor. Ezen a téren Magyarország valóban jól teljesít, de ez nem is véletlen, hiszen ennek érdekében alakult ki az uniós pénzekkel foglalkozó intézményrendszer. Ugyanakkor először Váradi Balázs hívta fel a figyelmet 2006-ban az uniós strukturális alapokból a 2007-2013 között várható 8000 milliárd Ft várhatóan negatív hatásaira. A fejlesztéspolitikai szakirodalomból jól ismert, hogy a bőségben található természeti erőforrások vagy a fejlődő országoknak juttatott segélyek - nem megfelelő intézményrendszer és a jó kormányzás hiányában - járadékvadászatra csábítanak és eltorzítják a piacot (Váradi 2006). A korrupciós és piactorzító hatáson túl az uniós források veszélyt jelentenek azért is, mert megjelenésükkel kiváltják a politikaalkotást, lepusztítják a meglévő intézményrendszert és tetemes forrást szívnak ki a költségvetésből, egyrészt a 25 százalékos önrész miatt (Hermann-Varga 2011), másrészt mert sokszor a mủködtetést is egyszerübbnek tűnt ebből a forrásból finanszírozni (Radó 2010). Egy forráshiányos régióban tehát, ahol a fejlesztések szinte csak uniós forrásokból finanszírozódnak, ezek az uniós pénzek nemhogy nem jelentenek addicionális forrásokat, de nem szándékolt hatásként ellehetetlenítik a hazai forrásból hazai célokat kitűző fejlesztési kezdeményezéseket. Éppen ezért önmagában a magas abszorpciós készség még nem garanciája annak, hogy ezek a pénzek valóban jól hasznosulnak. Ehhez meg kell vizsgálni a megvalósuló programok eredményességét.

A fejlesztéspolitikai beavatkozások hatását elemző szakértők egybehangzó véleménye, hogy a beavatkozások eredményességét alapvetően az adott országban fennálló intézményrendszer (amibe a jó kormányzástól az adott kulturális szintig sok minden beleérthető) fejlettsége és minősége befolyásolja (Szepesi-Törőcsik 2011; Nyikos 2013; Váradi 2006; Setényi 2011). A korrupciós és diszkriminációs jelenségek viszont rontják a hatékonyságot (Nyikos 2013).

A tanulmány nagyban épít az Innovatív hálózatok létrehozása nevelési-oktatási programok fejlesztésére című 2014-es OH projektjében elkészült elemzésre. 


\section{Az uniós fejlesztések hatása az oktatás eredményességére}

Az uniós források felhasználásának gyenge hatékonyságát az oktatás terén már a PISAfelmérésen tapasztalt magyar eredmények is mutatják (Csüllög-D. Molnár-Lannert 2014; PISA 2012, 2015). A KPMG az uniós források 2007-2013 közötti magyarországi felhasználásáról szóló jelentésében a támogatott és nem támogatott iskoláknak az Országos kompetenciamérésen nyújtott teljesítményét összehasonlítva hasonló eredményre jutott. A jelentésben olvashatjuk, hogy az oktatási szektort érintő fejlesztések összességében több mint 450 milliárd Ft értékben járultak hozzá a hazai emberi tőke és a jövő generációjának fejlesztéséhez. Ebből körülbelül 280 milliárd forint infrastrukturális természetű támogatás volt TIOP- és ROP-forrásokból, amelyek a felsőoktatás és a közoktatás infrastruktúrája különböző aspektusainak megújítására fordítódtak, további, összesen 170 milliárd forint pedig humán jellegü fejlesztésekben, képzésekben hasznosult a TÁMOP finanszírozásában. Ez utóbbiaknak mintegy a fele - körülbelül 90 milliárd forint - kifejezetten a hátrányos helyzetű tanulók felzárkóztatása céljából került elköltésre (KPMG 2017).

A jelentés kiemeli, hogy a kompetenciamérés eredményei alapján „nincs lényegi különbség a támogatott, illetve nem támogatott iskolák tanulóinak országos kompetenciamérési, illetve érettségi eredményeinek változásában a vizsgált időszakban, tehát a támogatások ezen az időtávon nem eredményeztek kimutatható javulást az eredményekben függetlenül attól, hogy infrastrukturális, vagy humán tőke fejlesztési beavatkozásokról van szó”.

Látványosan kimutatható különbségek vannak az egyes támogatások szociális célzottsága tekintetében. A támogatott általános iskolák körében többségben vannak az átlaghoz képest rosszabb szociális helyzetű intézmények (különösen az infrastrukturális fejlesztések esetében), míg a középiskolák esetében fordított a trend, a leghátrányosabb szociális helyzetű iskolák mellett jelentős támogatási arány jelenik meg az intézmények legjobb 40\%-ánál, amelyek támogatások nélkül is eleve jobb helyzetü diákokkal dolgoznak.

Az általános iskolák esetében tehát jobban céloztak, hiszen eleve a rosszabbul teljesítő, vélhetően hátrányosabb szociális helyzetü diákok iskoláiba került a támogatás. Ugyanakkor figyelemre méltó, hogy a támogatott és nem támogatott intézmények közötti „olló” a 30-40 pont körüli különbségről kiindulva (elsősorban 2012-től) 50-60 pont közeli különbségig nyílt. A középiskolák esetében a két kategória közti olló az általános iskolákénál jóval kisebb mértékben növekedett, de ez nagyrészt annak tudható be, hogy mind a kedvezményezett, mind a nem kedvezményezett intézmények mutatói esetén nagyjából hasonló mértékű romlás következett be.

A legjobban célzottnak a felzárkózást segítő projektek, a célzott esélyegyenlőségi fejlesztések tünnek, amelyek minden korosztályban a leghátrányosabb helyzetű iskolákban koncentrálódnak - „kimutatható hatásuk ugyanakkor ezeknek is nagyon kicsi a tanulmányi eredmény vonatkozásában, itt azonban a tanulmányi eredmény javítása mellett az iskolarendszerben való megtartás eredményessége javulhatott". (KPGM 2017.) Ennek viszont ellentmond az a tény, hogy Magyarországon a korai iskolaelhagyók aránya romlik, 2016-ban a korai iskolaelhagyók aránya a 10,7\%-os uniós átlag fölé, 12,4\%-ra emelkedett (Bizottsági Szolgálati Dokumentumok 2018). 


\section{Oktatásfejlesztési lépések vizsgálata}

Mint láttuk, a magyarországi uniós forrásokból finanszírozott fejlesztéseket nem tekinthetjük eredményesnek a tanulói eredmények alakulásának tükrében. A romlást részben magyarázza az oktatásra szánt költségvetési összegek csökkenő aránya. Érdemes ugyanakkor megvizsgálni azt is, vajon az alacsony hatásfoknak nem lehet-e egyéb magyarázata is, hiszen minden bizonnyal komplex hatások működnek közre. A fejlesztéspolitika olyan lépéseit érdemes górcső alá venni, mint a célok és eszközök kijelölését, az implementáció folyamatát, a programok értékelését és ezek visszacsatolását.

\section{Jól jelöljük ki a célokat és az eszközöket?}

A hazai és nemzetközi szakirodalomban is felerősödtek azok a kritikai hangok, amelyek az implementáció mikéntjének fontosságára hívják fel a figyelmet (Fazekas-Halász 2012). Amennyiben pusztán az implementáció elmaradását vagy nem megfelelő módját tekintjük a beavatkozás hátastalanságának okaként, akkor ezzel azt feltételezzük, hogy a célok és eszközök jól lettek kijelölve. Holott már a fejlesztéspolitika eme első fázisánál is detektálhatunk hiányosságokat.

A célokat a strukturális alapok hozzáférésénél az Unió állítja fel. Problémát okozhat, ha az adott ország céljaival ezek kevésbé harmonizálnak. Ilyenkor lép fel az ügynökmegbízó probléma, ahol az uniós célok mögött más célokat próbálnak hazai szinten elérni. Ilyenkor szinte automatikusan fellép a célok és eszközök közötti diszharmónia. A 2013-2020 közötti időszakban a lemorzsolódás csökkentése vagy a diplomások arányának növelése a kiemelt uniós célok. Az iskolakötelezettség korhatárának 18 évről 16 évre való visszaállításával, az egyházi intézményrendszer megerősítésén át az iskolarendszer szelektivitásának fokozásával (Fejes-Szücs 2018), a felsőoktatási felvételi követelmények szigorításával viszont Magyarország mintha nem ezeket a célokat követné.

A hátrányos helyzetű tanulók felzárkózását, a lemorzsolódás csökkentését szolgálná a tanoda program. A tanodák munkáját értékelő elemzések azt mutatják, hogy a tanodák hatása kimutatható ugyan, de elsősorban a mechanikus ismétlést alkalmazó korrepetálások által javítható alapszintű matematikai ismeretek terén. A bonyolultabb problémamegoldó készségeket igénylő feladatok terén javulás nem volt kimutatható. Ráadásul a tanodás és nem tanodás gyerekek közötti különbség nem volt számottevő, mindkét csoport kompetenciáinak szintje meglehetősen alacsonynak bizonyult. A tanodák eredményessége jól láthatóan nem függetleníthető el a környező iskolák minőségétől (Lannert-Németh 2013).

A tanulói eredményesség javítását nem a magyar, a gyakorlatot jellemző túlnyomóan mechanikus ismétlésre alapozó korrepetálás segíti elő. A PISA-adatok mélyebb elemzése is rámutatott arra, hogy a nem megfelelő iskolai tanítást nem tudja kompenzálni az iskolaidőn túli mechanikus és extenzív korrepetálás (Csüllög-D. Molnár-Lannert 2014). Ahhoz, hogy a valódi problémamegoldó készség és az ezt erősítő motiváció kialakuljon, időre van szükség, amikor a tanulók ki tudnak bontakozni egy értő közegben. Az általános iskola első négy éve kiemelkedő jelentőségű. A nemzetközi példák azt mutatják, hogy az eredményes országokban az iskolai problémákat nem az iskolán kívül, hanem az iskolán belül próbálják megoldani. Az egyik ilyen gyakorlat a kisebb gyermekek bioritmusát és életkori sajátosságait jobban figyelembe vevő egész napos iskolai oktatás. A portugál 
alsó tagozatos iskolareform azáltal, hogy bevezette az egész napos iskolai programot és komoly továbbképzést kínált az alsó tagozatos tanítóknak, valamint megszüntette a kisiskolákat és nagyobb körzetekben alakított ki iskolacentrumokat a helyi területi vezetők és a lakosság konszenzusával, komoly sikereket tudott elérni (Matthews et al. 2008). Ezen az iskolafokozaton azonnal csökkent a bukási arány, majd a PISA-eredmények terén is Portugália lett az egyik legdinamikusabban fejlődő ország. ${ }^{2}$

Ma Magyarországon nemcsak hogy egyszerre létezett / létezik két egymásnak ellentmondó elképzelés, mint az egész napos iskola és a tanoda, de ezek gyakorlati megvalósulása éppen, hogy a rendszer eredménytelenségét konzerválja. Az alapprobléma az alsó tagozatos oktatás színvonala, de ezt a problémát az uniós fejlesztések és célrendszer logikájába illeszkedve a tanodákkal próbáljuk orvosolni. Ez viszont nem hat vissza az alapoktatás minőségére, nem igazán preventív és adaptív beavatkozás. Viszont a tanodára költött fejlesztési pénzek valójában csökkentik az alsó tagozat fejlesztésére költhető költségvetési pénzeket és a honi stratégiaalkotási készséget, így a valódi probléma - az alsó tagozatos oktatás problémája - orvosolatlan marad. Jól illusztrálja ez az eset, hogy a tények alapos elemzésének hiánya és a háttérben meghúzódó erős helyi érdekeltségek hogyan segítik a zsigeri és az uniós kitüzésekkel célellentétes hazai megoldások szárba szökkenését.

\section{Implementáció}

A fejlődő országokba áramló segélyek és egyéb fejlesztési támogatások tapasztalatai a világbanki szakértőket is korábbi fejlesztéspolitikai paradigmáik újragondolására késztették. A közgazdasági értelemben racionálisan cselekvő ember illúziónak bizonyult, éppen ezért önkritikát gyakorolva ök is az adaptív design és adaptív beavatkozás mellett teszik le a voksukat (Mind, Society 2015). Ma már a központi fentről lefele irányított, lineáris ok-okozati összefüggésekre alapuló beavatkozások helyett a helyi kontextus ismerete és a helyi szereplők és igényeik elismerése és beemelése, involválása az új irány a nemzetközi fejlesztéspolitikában.

\section{Implementációs problémák a Világbank szakértői szerint}

- A közgazdászok arra koncentráltak, hogy a kormányoknak mit kell tenniük, sokkal kisebb hangsúlyt kapott az, hogy ezt a „mi”-t hogyan lehet elérni.

- A jó minőségű szolgáltatásokat a hatékony, szabálykövető, meritokratikus és politikailag elszámoltatható intézmények tudják biztosítani. Ennek sok formája lehet, de a puszta utánzással (mimikri) nem érhető el eredmény.

- A nem megfelelő szolgáltatás problémáját szinte mindig központosított, bürokratikus és top-down egységes közszolgáltatásokkal próbálták megoldani. A fejlesztéseknek standard szervezeti algoritmusa a következő: a probléma a hiány, a megoldás a kínálat és az eszköz a közszolgáltatás volt. Pedig nincs univerzális megoldás.

2 Lásd Andreas Schleicher (az OECD PISA-részlegének vezetője) előadását a TED-en. Akkor Portugália mellett még Magyarország is jó példa volt a kiugró 2009-es javulással a szövegértés terén. http://www.ted. com/talks/andreas_schleicher_use_data_to_build_better_schools?language=en [Letöltve: 2018. 12. 03.] 
Az új megoldásoknak két jellegzetességük van: részvétel, transzparencia, elszámoltathatóság és jó kormányzás, valamint hogy ezek intézményileg heterogén módon valósulnak meg. Nincs olyan, hogy egy méret mindenkinek megfelel.

Forrás: Pritchett-Woolcock 2004

A lineáris leegyszerüsítő beavatkozási logika általában visszamenőleg beavatkozó logika, hiszen hiába hasznosabb a preventív szemléletủ beavatkozás, ez utóbbi jóval nagyobb megértését igényli az emberek viselkedésének és a cselekedeteiket befolyásoló ösztönzőknek. Ugyanakkor az implementáció kapcsán gyakran elfelejtődik az időtényező fontosságának szerepe. Mint ahogy az is igaz, hogy a „fejlesztés nem egy vákuumba érkezik", és az is igaz, hogy egyik pillanatról a másikra nem lehet sikert elérni. Mint ahogy az innovációknak és a start-up cégeknek, az oktatásfejlesztési beavatkozásoknak is az intézmény szintjén van érési idejük. Az oktatási fejlesztések esetén is létezik egy „implementációs gödör”, mint ahogy egy innováció teljes beérése is legalább - hazai iskolai környezetben - hét év (Micheal Fullan után Fazekas-Halász 2012: 75). Amennyiben tehát nem a megfelelő implementációs technikákat alkalmazzák, vagy nem jól, vagy nem hagynak elég időt rá, úgy gyakran a szándékoktól eltérő hatást érhet el a fejlesztés. Ugyanígy a fejlesztéseknek nemcsak a mikrokörnyezete, de a makroszintü környezete is erősen befolyásolja az eredményességet. Amennyiben a tanuló és együttmüködő hálózatok, intelligens és autonóm tanulószervezetek jelentik a siker kulcsát, úgy egy centralizált és központosított környezet ennek ellenébe hat. Egy ilyen környezetben az elszigetelt fejlesztések előbb-utóbb elhalnak, és nem lesznek fenntarthatók. A tudatos implementáció hazai mintájának szokták felhozni az 1995-ös NAT bevezetését, ahol elemezték az érintett csoportokat és várható viselkedésüket (Pőcze 1995).

\section{A fejlesztések értékelése és visszacsatolása}

Habár a hibáinkból tanulunk leginkább, a fejlesztéseknek az ezt a célt is szolgáló értékelése a leggyengébb láncszem nálunk és az Unióban egyaránt. Az uniós értékelésekről a megvalósításban részt vevő szakértő értékelését egy hazai oktatáspolitikai blogon olvashatjuk:

„A megrendelö nem volt különösen motivált, az értékelés Brüsszelben kötelezö. A Föigazgatóság (érthetőbb nevén DG Employment) elvárása a korábbi müködési és értékelési hagyományba belesimuló munka lett volna, részterületenkénti látványos adathalmaz némi leíró szöveggel, amely - lehetöleg - pozitív hatást (impact) mutat ki a különbözö területeken eszközölt ESZA-berubázások kapcsán. (Az Unió politikáit hagyományosan nem az értékelési jelentések dinamizálják.)" (Setényi 2011.)

Pedig az uniós fejlesztéspolitikával foglalkozó szakértők szerint is valójában az értékelés erősíti leginkább az uniós kohéziós politika és a nemzeti támogatáspolitikák egymást erősítő és folyamatosan javuló kapcsolatát. Az Unió is érzékeli, hogy a korábban alkalmazott értékelések leginkább az elért célokat listázták fel, de semmit sem árultak el a si-

3 Linda Darling Hammond elhíresült mondása. 
kerek és kudarcok okairól, így kevés kapaszkodót jelentettek a tanuláshoz. Ráadásul ezek az értékelések szinte soha nem mentek le projekt szintre, így meglehetősen általánosak maradtak, nagyon gyakran a programmenedzsment volt az értékelés fókuszában. Éppen ezért az uniós hatásvizsgálatok (impact analysis) két formáját javasolja használni a jövőben. Egyrészt az elméletalapút (theory based), amely vegyes módszertannal (kvalitatív és kvantitatív egyszerre) elsősorban formatív értékelést tenne lehetővé, ami a programok megvalósítását és fenntarthatóságát segítheti. A másik, a tényellentétes (counterfactual) hatáselemzés pedig kontrollcsoportok bevonásával azt vizsgálja, hogy a beavatkozás elmaradása milyen hatással járt volna (Sági-Széll 2015). Ugyanakkor e két módszer ajánlását nem kíséri a korábbi módszerek részletes elemzése és bírálata, ahogy az új módszer implementálásának javaslata sem. Így - a szakértők szerint -, „amennyiben pusztán a régi problémákra új megoldásokat javaslunk anélkül, hogy elemeznénk, miért nem müködtek a korábbi mechanizmusok, akkor lehetséges, hogy megint csak vizet hordunk egy lukas vödörbe" (Polvari 2016).

Az oktatási programok értékelése gyakran el is marad, mert a hatás jóval a projekt vége után lenne mérhetö, és ennek költsége nincs beleépítve az uniós fejlesztési projektlogikába. Gyakran nincs mód valódi bemeneti és kimeneti mérést egyaránt tartalmazó, valamint a folyamatot monitorozó és kontrollcsoportot is bevonó akciókutatás típusú értékelésre, mert ehhez már a program elindításakor nagyon erős koncepcionális elképzelés kell a program céljairól és eszközeiröl. Ennek hiányára utal, hogy a programok szinte mindig bemeneti mérés nélkül indulnak el. Így nincs mihez viszonyítani a projekt végén elért eredményeket. Az ilyen jellegü értékelések ráadásul komoly interdiszciplináris teammunkát igényelnek, hiszen a pedagógiai, szociológiai, közgazdaságtani és méréstechnikai, pszichológiai szaktudás egyaránt szükséges. Az értékelések alacsony színvonala vagy elmaradása mögött azonban leginkább az érdekeltség hiánya áll, ez viszont megakadályozza azt a tanulási folyamatot, amivel a fejlesztések a hibáikból tanulva egyre eredményesebbek lehetnének.

\section{Strukturális problémák}

Még ha tudjuk is, hogy a fentről lefele megközelítés nem eredményes, és a kontextusból és „alulról” kell kiindulni a fejlesztések során, ezzel még nem lesz egyértelmü, milyen operatív lépésekre is lenne szükség ahhoz, hogy a fejlesztés gyökeret eresszen és fenntarthatóvá váljon. Sőt, van, aki azt állítja, hogy magával a megközelítéssel van a gond, éppen a megoldás (fejlesztés) a probléma (Pritchett-Woolcock 2004). Azzal a közpolitikai fejlesztések standardizált algoritmusaként funkcionáló megközelítéssel, amely a szükséget tekinti problémának, a megoldást a kínálatban látja, és a közszolgáltatást tekinti a megoldás eszközének. Természetesen voltak ennek a szemléletnek sikerei is (mint például bizonyos járványok leküzdése, az analfabétizmus felszámolása, halálozási ráta csökkentése), de többségében inkább kudarcokkal járt. A világbanki szakértők álláspontja szerint a sok tranzakcióval járó diszkrecionális döntéseken alapuló területek, mint az oktatás vagy az egészségügy, nem fejleszthetők sikeresen projektekkel. Megkülönböztetnek tranzakcióintenzív és nem intenzív, illetve diszkrecionális vagy nem diszkrecionális döntéshozatali módokat a közszolgáltatás terén (lásd 1. táblázat). Minél többször kerül valaki kapcsolatba az ügyféllel, mint a pedagógus vagy az orvos, annál inkább beszélhetünk intenzív tranzakcióról és minél inkább saját hatáskörükben döntenek (mint a 
tanár az osztályteremben vagy az orvos a rendelőben), annál inkább beszélhetünk diszkrecionális döntésről. A szolgáltatások terén általában diszkrecionalitást tapasztalhatunk, ahol a helyi döntések meghozatalához szükségesek a helyben megszerezhető információk (a tanulók vagy betegek állapota), így nem müködhet mechanikusan. Minél kevésbé függ a döntés a kontextustól, annál kevésbé beszélhetünk diszkrecionalitásról.

A diszkrecionális, de nem tranzakcióintenzív döntéshozatali tevékenység a szakmapolitika (policy) területe. Tíz okos ember összeül és meg tudja alkotni a szakmapolitikai stratégiát, reformelképzeléseket. Ha belegondolunk, Magyarországon szinte minden stratégia, fehér vagy zöld könyv hasonló logikában készült el. A nem diszkrecionális és nem tranzakcióintenzív területen találhatjuk a szabályokat és eljárásokat, ami a magyar döntéshozatalban mindig is kitüntetett terület volt. A programok viszont sok tranzakcióval járnak, de nem diszkrecionálisak, rutinizáltak. Egy program implementációja szoros „használati útmutatót” igényel, ahol viszonylag kevés a választási lehetőség, és elsősorban technikai (költséghatékony megoldást találni) és logisztikai (megbízhatóan végig menedzselni a folyamatot) problémák állnak az előtérben. Az oktatásfejlesztési projektek a meglehetősen merev elöírásokkal és beszámolási kötelezettségekkel ebbe a logikába simulnak bele. Holott a napi gyakorlatot másképp kellene megközelíteni. A diszkrecionális döntésekkel teli tranzakcióintenzív "gyakorlatok” okozzák a legnagyobb fejtörést, mert eredendően nem illenek bele a nagy volumenű, rutinizált adminisztratív ellenőrzés logikájába.

1. táblázat: A közszolgáltatások döntéshozatali mód szerinti tipizálása

\begin{tabular}{lll}
\hline & Diszkrecionális & Nem diszkrecionális \\
\hline Tranzakcióintenzív & Gyakorlat, praxis & Program \\
& Pl. a napi tanítási vagy a gyógyítási & Pl. iskolaétkeztetési vagy oltási \\
& gyakorlat & programok \\
\hline Nem tranzakcióintenzív & Policy & Eljárások, szabályok \\
& Pl. tantervi reform vagy felvilágosító & \\
& kampány & \\
\hline
\end{tabular}

Forrás: Pritchett-Woolcock 2002

A szakmapolitika elsősorban technokrata, a programok pedig bürokrata logikát követnek, míg a napi praxis elsősorban egyénit. A gyakorlatokat nem lehet standardizálni. Éppen ezért e hiátust legtöbbször a jó gyakorlatok gyüjtésével próbálják kezelni. Ugyanakkor a jó gyakorlatoknak igencsak csalóka a fényük, amennyiben helyi adaptáció és átgondolás nélkül kerülnek bevezetésre, bizonyosan nem éri el a fejlesztő a célját. A jó gyakorlatok emésztetlen átültetése leginkább arra utal, hogy hiányzik a stratégiai átgondolás és a helyi kontextus alapos ismerete. Gyakran az ún. interpretációs tévkövetkeztetések (ecological fallacy) sorába helyezik, ahol azt tételezik, hogy egy modell puszta formai lemásolása, mimikrije önmagában megoldás lehet. Ilyennek tekinthető a civil tanodák állami szinten központosított és standardizált fejlesztése vagy a fel-felbukkanó 9 évfolyamos általános iskola bevezetésének ötlete. Emögött minden bizonnyal a lengyel oktatási reform és az 1999-ben bevezetett oktatásszerkezeti reform közötti téves ok-okozati kapcsolat feltételezése áll. A lengyel siker mögött nagyon sok egyéb, kulturális és kontextuális tényező állhat, mint a pedagógus életpályamodell továbbképzés központú 
bevezetése vagy a tankönyvek szisztematikus, tényalapú fejlesztése. Egy olyan rendszerben, ahol nem csökken a tanulónépesség és nincsenek az alapfokra lenyúló középiskolai szerkezeti megoldások, egész másképpen funkcionál a kilenc évfolyamos általános iskola, mint ahol csökken a gyereklétszám és az iskolaszerkezet nagyon színes, a rendszer pedig erősen szelektív. Egy ilyen megoldás csak akkor működik, ha a szerkezetváltó gimnáziumok megszünnek, ellenkező esetben az általános iskola felső évfolyamai elfekvőre fognak hasonlítani.

A tranzakcióintenzív diszkrecionális gyakorlat központi fejlesztése három okból is kudarcot vallhat.

1. Nagyon sok szintje van a problémának és ezzel az ún. ügynök-megbizó probléma megsokszorozódik. Minden szinten találhatunk egy megbízót, aki megbízza az ügynököt a fejlesztéssel. Az ügynök általában jobban ismeri az adott viszonyokat, az aszimmetrikus információs helyzet viszont akár visszaélésre is csábíthatja a megbízottat, hogy visszaéljen a megbízó által adott forrásokkal, célokkal stb. A megbízó pedig - hogy kontrollálhassa a megbízottat - szükségtelenül sok adminisztratív kontrollt helyez a rendszerbe. Különösen halmozott ügynök-megbízó problémával állunk szemben az uniós fejlesztések terén. Alapvetően az Európai Unió országainak az állampolgárai a megbízók, akik Európa fejlesztését várják el a politikusoktól. A brüsszeli politika megbízza a brüsszeli bürokratákat a fejlesztések koncepciójának kidolgozásával, menedzselésével. A brüsszeli bürokraták megbízzák az országok minisztériumait, hogy az európai célokat nemzeti célokká alakítsák át. A minisztériumok megbízzák a háttérszervezeteket, hogy a részleteket kidolgozzák. A háttérszervezetek megbízzák a projektmenedzsmentet végző közvetítő szervezeteket a lebonyolítással, azok pedig pályázatok útján megbízzák a projektek végrehajtásával az erre mandátumot kapott szervezeteket, intézményeket, cégeket. A hosszú láncolatban számtalan ügynök-megbízó párost találunk, amelyeknél mindig felmerül annak a veszélye, hogy az ügynök a megbízót félrevezeti. Ilyennek tekinthető például, amikor a nemzeti kormányok és minisztériumai megpróbálják saját céljaikat az uniós célok mezébe csomagolni, és így születnek olyan operatív programok, amelyek megpróbálják a nemzeti célokat elérni uniós keretek között. Minél nagyobb az eltérés a helyi és az uniós célrendszer között, annál nagyobb annak a veszélye, hogy a megbízó (itt az Unió) céljai nem fognak teljesülni. Ennek érdekében erősebb kontrollt gyakorol, de ez esetben a nemzeti célok fognak csorbát szenvedni. Ugyanilyen párost alkot a projektmenedzser közvetítő szervezet és a projektet végrehajtó szervezet. Nagyon gyakori, hogy az iskolák - kellő erőforrás híján - kénytelenek saját helyi céljaikat a meglévő pályázatok útján érvényesíteni, hiszen ez az egyedüli pénzforrás a fejlesztés számára. Így bármilyen pályázatot megpályáznak, még akkor is, ha az nem a céljaiknak megfelelő, remélve, hogy a pályázat örvén saját céljaikat is elérik. A projekt eredménytelensége ilyen konstellációban szinte kódolható.

2. A közszolgáltatások azon közjavak létrehozására hivatottak, amelyeket a piac maga nem hoz létre, mert túl sok költséggel jár az egyéni szinten elérhető nyereséghez képest, miközben a közösség szintjén ezek a javak szükségesek. Az általános közoktatás vagy közegészségügy ilyen területek. Ugyanakkor a piac kiiktatása egyben csökkenti a hatékonyságot, hiszen a piac tisztító hatása nincs jelen. A közalkalmazottak esetén tapasztalható ez, amikor a munkáját nem jól végzőket nem tudják elbocsátani, noha ez egy vállalatnál megoldás lehetne. 
3. A diszkrecionalitás ilyen esetekben a hatékony szolgáltatás alapja, így ha ezen a területen a nagyobb kontroll érdekében a megbizottól elvonják a saját döntési jogkört, ezzel ugyan csökkenthetik a visszaélés lehetőségét, de egyben csökkentik az eredményességet is.

\section{Fejleszthető-e az oktatás fenntartható módon és eredményesen projektek által?}

A probléma tehát az, hogy a napi gyakorlatot olyan eszközökkel próbáljuk javítani, amelyek erre nem alkalmasak: szakmapolitikai reformmal, rendeletekkel, programokkal, projektekkel. Ezek a megoldási formák az erőforrásokat központosítják és csatornázzák, az információkat monopolizálják és felülről lefele áramoltatják (vissza vagy horizontálisan nem), a döntéseket a kormány vagy annak ágensei hozzák, a fejlesztő ügynökségek vagy közvetítő intézmények a központtól szállítanak a helyi felé, az elszámoltathatóság pedig belső és alulról felfele irányuló folyamat, az állampolgárok felé való elszámoltathatóság nincs a fókuszban. Így még az indokolt fejlesztések is kudarcot vallanak a fejleszteni vágyott, de be nem vont helyi szereplők alulmotiváltsága és érdektelensége miatt. A szükséglet-kínálat-közszolgáltatás megközelítés eredménye az oktatásban: központosított tanterv, alulképzett pedagógus, alacsony helyi elköteleződés, a folyó kiadások nagy arányban bérekre költése, alacsony tanulási teljesítmény, nagy lemorzsolódás. A visszacsatolás hiánya és a helyi szereplők be nem vonása mindenképpen kudarchoz vezet, de ezt gyakran elhomályosítja az a tévképzet, hogy ezek a dolgok máshol müködőképesek. Pedig a jó gyakorlatok szolgai másolása, a problémák technicizálása (például amikor az oktatási indikátorokat mechanikusan akarják használni és az iskolaszerkezeti átalakítást egyszerü mérnöki feladatnak tekintik), az egységes megoldások mámora nem megoldás. A probléma viszont másik oldalról is megközelíthető. A fejlettebb országok saját berendezkedéseiket példaként állítják a kevésbé fejlettek elé és ez alapján ítélik meg működésüket. Ezek a veszélyek az uniós fejlesztési logikában halmozottan fennállhatnak, ahol erre szakosodott fejlesztési szakértők kérnek el súlyos pénzeket kontextusfüggetlen és nagy eséllyel eredménytelen megoldási javaslataikért, gyakran csak azt az előnyt kihasználva, hogy szerencsés helyen születtek.

A hibákra viszont gyakran hibás megközelítéssel válaszolunk. A világbanki szakértők több hibás választ is felsorolnak (Pritchett-Woolcock 2002):

1. Intenzifikálás. Ha nem tanít jól a tanár, lássuk el még több képzéssel. Ha a fenntartási kiadások alultervezettek, tegyünk még több pénzt a rendszerbe. Nagyon gyakran ezek a válaszok a valódi változtatások helyett a könnyebbik, ún.járulékos reformot preferálják, és csak a többszöri kudarccal végződő intenzifikáló kör után jön a felismerés, hogy habár ez máshol müködött, de itt másra van most szükség.

2. Amputálás. Ez a fajta doktriner „amputálás” vagy államtalanítás igen jellemző volt a posztszocialista országok átmeneti periódusára. Ennek kockázata, hogy fontos feladatok ellátatlanok maradnak. Ez a fajta szemlélet mindig új lendületet nyer, amikor pénzügyi megszorításokra van szükség. Ugyanakkor éppen ezek a kulcsterületek azok (oktatás, egészségügy stb.), ahol az állami felelősség miatt a kormány nem vonulhat ki. $\mathrm{A} z$ állami feladatokat egy gyenge állam még kevésbé tudja megoldani. Habár sajnos hatalmas költségvetés mellett is előfordul, hogy alacsony a szolgáltatás színvonala, de költségvetés nélkül maga a szolgáltatás is megszűnik. 
3. Szakmapolitikai reform. A szakmapolitikai reform általában olyan reformokat takar, amit kevés „okos” emberrel is implementálni lehet. Tény és való, hogy az ázsiai országok reformjai mögött gyakran egy vékony technokrata elit állt. Ez akkor müködik, ha nem kell széles körű vitákba bocsátkozniuk, erős támogatásuk van felülről, és eléggé beágyazottak. Ugyanakkor a szük körű elit reformja magában hordozza azt a veszélyt, hogy túlbecsülik képességeiket, hogy csak egy szük, általuk preferált területre koncentrálnak és teljesen különböző problémákat is hasonlóan egységes, standardizált módon közelítenek meg. Előnyben részesítik a diszkrecionális, de nem tranzakcióintenzív döntési módokat, és gyakran az elefántcsonttoronyból szemlélve, a reformok kudarcát a tudatlanságnak, a kompetenciák hiányának és a közömbösségnek tudják be. "Tiz okos ember lehet, hogy tudja, hogyan kell egyesböl a kettes sebességbe váltani, de nem sokat érnek vele, ha közben nem veszik észre, hogy az autó fékje és jelzölámpája nem müködik, a kerék lapos, a soförnek nincs jogositványa, az út sikos." (Pritchett-Woolcock 2004: 20.) Az elit kis csoportja nem tudja növelni az oktatás színvonalát, ha tanárok ezreinek mindennapi gyakorlatát nem változtatja meg.

4. Mimikri - amikor egy jó gyakorlatot pusztán szolgai módon lemásolunk, de nem adaptáljuk a helyi igényeknek és lehetőségeknek megfelelően, és nem engedjük meg a modelltől való kreatív eltéréseket.

5. Túlterhelés - amikor a hatékonyságot és eredményességet a gyorsan és sokat szemlélet váltja fel, ezáltal túlságosan is megterhelve a szereplőket, és a rövid határidők és terhek túlfeszítik a kereteket.

Mégis, hogyan lehet akkor megoldani, hogy az osztálytermi gyakorlat minősége javuljon az oktatásban? A fejlesztéspolitikai szakértők éppen arra hívják fel a figyelmet, hogy nincs általánosan jól müködő egységes recept. Vannak olyan tények, amelyek segítenek, mint a jó intézmények, a jó kormányzás, a differenciált megközelítés, a szereplők aktív részvétele, a szolgáltatók elszámoltathatósága, de ezek egyéni kombinációját minden országnak magának kell átgondolnia, kidolgoznia.

A fejlesztéspolitikában egy új paradigmaváltásra próbálkozás a CDD (Cash on Delivery) segélyezési forma, ahol a segélyt nyújtó donor nem előre szabályozott projekteket támogat, hanem a segíteni kívánt országgal csak a célokban egyezik meg, amit egyedi módon közelíthetnek meg, a pénzeket viszont az eredmény függvényében és harmadik „független” fél igazolásával folyósítják. Ezzel a jó gyakorlat másolást a feje tetejére állítják, hiszen éppen nem a jó gyakorlatok, modellek „külalakja” számít, hanem a dokumentált eredményesség. Ezáltal a projektgazda nincs Prokrusztész ágyába kényszerítve. A másik fontos újdonság a CDD programmal kapcsolatban, hogy annak eredményességét nem a program, hanem a rendszer szintjén mérik. Ezzel a rendszert a puszta formai másolástól továbblendítik oda, ahol a valódi - habár gyakran „bomlasztó” - innovációk lehetségesek. A jövő kérdése, hogy ez a forma hogyan vizsgázik, és sikerül-e legyőznie a szereplők kockázatkerülö, és éppen ezért jógyakorlat-másoló magatartását és elismertetni a kockáztatás jogosultságát (Pritchett-Woolcock-Andrews 2012).

\section{Kedvező környezet szükséges}

Az eredményes fejlesztés nem pusztán implementációs technika kérdése. Ahhoz, hogy a helyi szereplő valóban tevékenyen részt tudjon venni saját problémáinak eredményes 
megoldásában, egyrészt képesnek kell erre lennie (kompetenciák, felelősségek és erőforrások tekintetében), másrészt a hatalomnak bíznia kell benne (felvértezni a szükséges eszközökkel és hagyni munkálkodni). Kultúra kérdése is, hogy a szükséges kontrollmechanizmusok a kölcsönös elismerést vagy éppen a bizalmatlanságot erősítik. Előfordulhat, hogy egy folyamatosan nem hatékonyan müködő rendszerből folyamatosan tünnek el a kompetenciák és erőforrások, kiüresítve így a felelősség fogalmát. A társadalom és a politika már nem tudja felfogni az oktatást a maga komplexitásában. A leegyszerüsítő gondolkodás terméke a nagyfokú autonómia kontroll nélkül vagy a nagyfokú kontroll autonómia nélkül, holott az eredményes pedagógiai munka feltétele az autonómia és kontroll együttes, harmonikus jelenléte.

Míg a korábbi oktatáspolitika az intézményi autonómiát gyakran az iskolák magára hagyásával helyettesítette, addig most úgy tűnik, hogy a kontrollt a túlbiztosított centralizációval pótolják. Nem tűnik logikusnak, hogy egyszerre létezik egy központosított tankerületi rendszer, állami tankönyvkiadás és pedagógiai szakmai szolgáltatás, tanfelügyelet és elsősorban tantárgyi szaktanácsadók, valamint a kötelező pedagógus kari tagság. Egy túlbürokratizált rendszerben, ahol a centrális erőtér dominál, ott félő, hogy a pedagógusértékelés esetében is a különböző szereplők egysíkúan és egy irányba húznak, és kevésbé az eredményesség, mint a vonatkozó dokumentumok és az azoknak megfelelő viselkedés lesz a megítélés központjában. A pedagógiai autonómiát elfojtó túlcentralizálás és az anómiás, visszacsatolásként pusztán a piaci folyamatokra hagyatkozó liberalizálás között még nem sikerült megtalálni a középutat. Szükség van egy kiszámítható és fenntartható pedagógus életpályamodellre, valamint szakmai ellenőrzésre és támogatásra, de egy olyan intézményi struktúrában, ahol a szakmai autonómia és kontroll harmóniája megvalósul (lásd 2. táblázat). Elszámoltathatóság híján ugyanis az iskolai autonómia éppen hogy negatív összefüggésben áll az iskolai eredményességgel. ${ }^{4}$

2. táblázat: Elmozdulás a centralizált rendszerből a kontrollált szakmai autonómia felé

\begin{tabular}{ll}
\hline Centralizált túlbiztosított rendszer & Kontrollált szakmai autonómia \\
\hline $\begin{array}{l}\text { Klebersberg Intézményfenntartó Központ } \\
(\text { KLIK) }\end{array}$ & $\begin{array}{l}\text { Tankerületi rendszer, amely kistérségi szinten mü- } \\
\text { ködik és elsősorban a helyi igényekre reflektál. }\end{array}$ \\
\hline Pedagógus Kar & $\begin{array}{l}\text { Független tanári szakmai szövetség a pedagógi- } \\
\text { ai sztenderdek folyamatos felügyelete, alakítása } \\
\text { céljából. }\end{array}$ \\
\hline Tanfelügyelet & $\begin{array}{l}\text { Intézményértékelő inspekciós rendszer, ami nem az } \\
\text { egyéni pedagógusra van kiélezve, de része az osztály- } \\
\text { termi munka megfigyelése is. }\end{array}$ \\
\hline Szaktanácsadók & $\begin{array}{l}\text { A pedagógus és az intézményvezetők munkáját segí- } \\
\text { tő szakértői hálózat, akkreditált szakértőkkel és erre } \\
\text { célzott normativákkal az intézmények részére. }\end{array}$ \\
\hline
\end{tabular}

Fontos, hogy az EU fejlesztési források ne rontsák a működés feltételeit, ugyanis csak működő rendszereket, intézményeket lehet fejleszteni. Éppen ezért az uniós fejlesztéseket

4 PISA 2009 Results: What Makes a School Successful? Resources, Policies and Practices. Paris, OECD Publishing, 2010. 
sokkal jobban kell kötni a költségvetésböl finanszírozott müködéshez. Egyrészt fontos, hogy az oktatásra szánt költségvetés növekedjen, mert ez a projektek eredményeinek fenntarthatóságát garantálja. Másrészt úgy kell megtervezni a projekteket, hogy a fejlesztéseknek legyen költségvetési lábuk. Ehhez az is szükséges, hogy az uniós fejlesztéseknek ne a lehívási arány legyen a sikerindikátora, mert ennek magas aránya túl sok költségvetési pénzt vonhat el a mủködtetéstől, éppen ezért ez a sikerindikátor a valódi eredményesség megítélését tekintve célellentétesnek bizonyulhat. Sokkal inkább a szakmai szempontoknak kellene előtérbe kerülniük, és a jogi-pénzügyi kontrollt elviselhető mértékűre kellene visszaszorítani.

A projektkiírásoknál célszerü lenne az egyéni, de éppen ezért a helyi igényekre szabott és ezáltal eredményesebb megközelítéseket is megengedni. Az úgymond jó gyakorlatok elemeinek szolgai másolását és reprodukcióját elvárni célellentétes hatással jár. Miután az osztálytermi gyakorlat a pedagóguson áll, a napi müködést leginkább úgy tudjuk befolyásolni, ha a helyi cselekvő kompetenciáit, attitűdjeit formáljuk, így képzés, átképzés, mentorálás és szakmai támogatás szükséges. Célszerű az ösztönzők körébe az iskolai autonómiát is beemelni. Javasolt ennek differenciált növelése, vagyis a nemzetközi gyakorlatban sem ismeretlen módon az eredményes iskolák esetében nagyobb fokú autonómiát lebet megajánlani, de ehhez szükséges, hogy a tanfelügyelet intézményszintü értékelést végezzen. Csak akkor lesz működőképes a modell, ha maga a tevékenység, a kísérlet és tanulás öröme, és a várható nagyobb eredményesség a motiváció. De nem csak az egyéni országok szintjén szükséges az újragombolás. Amennyiben az uniós fejlesztések célja nem pusztán politikai, hanem szakmai is, akkor a fejlesztéspolitika terén nemcsak nemzeti, de uniós szinten is a rendszer alapos újragondolása szükségeltetik.

\section{IRODALOM}

Bizottsági Szolgálati Dokumentumok (2018) 2018. évi országjelentés - Az 1176/2011/ EU rendelet szerinti értékelés a strukturális reformok terén elért haladásról, a makrogazdasági egyensúlyhiány megelőzéséről és korrekciójáról, továbbá a részletes vizsgálat eredményeiről COM(2018) 120 final.

Csüllög K., Molnár D. É. \& Lannert J. (2014) A tanulók matematikai teljesítményét befolyásoló motívumok és stratégiák vizsgálata a 2003-as és 2012-es PISA mérésekben. In: Hatások és különbségek. Budapest, Oktatási Hivatal.

FAZEKAs Á. \& HalÁsz G. (2012) Az implementáció világa. Az európai uniós forrásokból megvalósított magyarországi oktatásfejlesztési beavatkozások empirikus vizsgálatának elméleti megalapozása. ELTE PPK Felsőoktatás-menedzsment Intézeti Központ. Kézirat. http://www.impala.elte.hu/produktumok-i-munkafazis/ [Letöltve: 2018. 12. 03.]

Fejes J. B. \& Szứcs N. (eds, 2018) Én vétkem. Helyzetkép az oktatási szegregációról. Szeged, Motiváció Oktatási Egyesület. https://motivaciomuhely.hu/wp-content/ uploads/2018/05/\%C3\%89n-v\%C3\%A9tkem_online.pdf [Letölte: 2019. 02. 07.]

Fullan M. (2008) Változások és változtatás - a ráadás. Budapest, Oktatáskutató és Fejlesztő Intézet.

Hermann Z. \& Varga J. (2011) A közoktatás finanszírozása. In: Balázs É., Kocsis M. \& VÁGó I. (eds, 2010) Jelentés a magyar közoktatásról 2010. Budapest, Oktatáskutató és Fejlesztő Intézet. 
KPMG (2017) A magyarországi európai uniós források felhasználásának és hatásainak elemzése a 2007-2013-as programozási időszak vonatkozásában. Beavatkozási terület szintü szakmai elemzések. KPMG. 2017. március 2.

Lannert J. \& Németh Sz. (2013) Tanodakutatás 2012/13. Zárótanulmány. T-Tudok Zrt. Kézirat.

Matthews, P., Klaver, E., Lannert, J., O’Conluain, G. \& Ventura, A. (2008) Policy Measures Implemented in the First Cycle of Compulsory Education in Portugal. Ministry of Education Portugal.

Mind, Society (2015) Mind, Society and Behaviour. World Development Report. World Bank Group.

Nyıkos Gy. (2013) A közfinanszírozásból megvalósított fejlesztések hatásai, különös tekintettel az EU kohéziós politikára. Pénzügyi Szemle, Vol. 58. No. 2.pp. 165-185. http:// real.mtak.hu/78889/1/165_185_nyikosgyorgyi_2013_2.pdf [Letöltve: 2019.02.07.]

PISA (2012) Összefoglaló jelentés. Budapest 2013. OH.

PISA (2015) Összefoglaló jelentés. Budapest 2016. OH.

Polverari, L. (2016) The New Ambitions for 2014-2020 European Structural and Investment Funds Evaluation Pouring Water in a Leaking Container? European Structural and Investment Funds Journal, Vol. 4. No. 2. pp. 59-67.

Pőcze G. (1995) A NAT és a gyakorlat: a Nemzeti alaptanterv implementációja. Új Pedagógiai Szemle, Vol. 45. No. 4. pp. 12-35.

Pritchett, L. \& Woolcock, M. (2004) Solutions When the Solution Is the Problem: Arraying the Disarray in Development. World Development, Vol. 32. No. 2. (February) pp. 191-212.

Pritchett, L., Woolcock, M. \& Andrews, M. (2012) Looking like a State: Techniques of Persistent Failure in State Capability for Implementation. CID Working paper, No. 239. Harvard University.

RAdó P. (2010) Az uniós források által okozott károkról. http://oktpolcafe.hu/az-uniosforrasok-altal-okozott-karokrol-343/ [Letöltve: 2019. 02. 07.]

Sági M. \& Széll K. (2015) Hatásvizsgálatok alapszintü kézikönyve. Módszertani segédkönyv oktatásfejlesztök számára. Budapest, Oktatáskutató és Fejlesztő Intézet. http://ofi.hu/ sites/default/files/attachments/1406447_hatasvizsgalatok_alapszintu_kezikonyve_ beliv.pdf [Letöltve: 2019. 02. 07.]

SetÉnyi J. (2011) Felvezető: az ESZA értékeléséről. http://oktpolcafe.hu/felvezeto-az-eszaertekeleserol-388/ [Letöltve: 2019.02.07.]

SetéNyi J. (2012) A korlátozott érvényességű fejlesztéspolitikáról. http://oktpolcafe.hu/akorlatozott-ervenyessegu-fejlesztespolitikakrol-869/ [Letöltve: 2019. 02. 07.]

Szepesi B. \& Törőcsıк G. (2011) Az átmenet gazdaságtana. Politikai gazdaságtani pillanatképek Magyarországon. Budapest, ELTE-MTA-Balassi Kiadó.

VÁrAdi B. (2006) Miért folyik a csata, avagy a 8000 milliárd átka. http://palyazatipenz. blog.hu/2006/11/03/miert_folyik_a_csata_avagy_a_8000_milliard_atka [Letöltve: 2019. 02.07.]

A cikk a Creative Commons Attribution 4.0 International License (https://creativecommons.org/licenses/ by/4.0/) feltételei szerint publikált Open Access közlemény, melynek szellemében a cikk bármilyen médiumban szabadon felhasználható, megosztható és újraközölhető, feltéve, hogy az eredeti szerző és a közlés helye, illetve a CC License linkje és az esetlegesen végrehajtott módosítások feltüntetésre kerülnek. (SID_1) 